\title{
NEPTUNIUM TARGET ELEMENT
}

FABRICATION

C. R. BLOOMSIER

DECEMSER 1967

\section{AEC RESEARCH \& DEVELOPMENT REPORT}

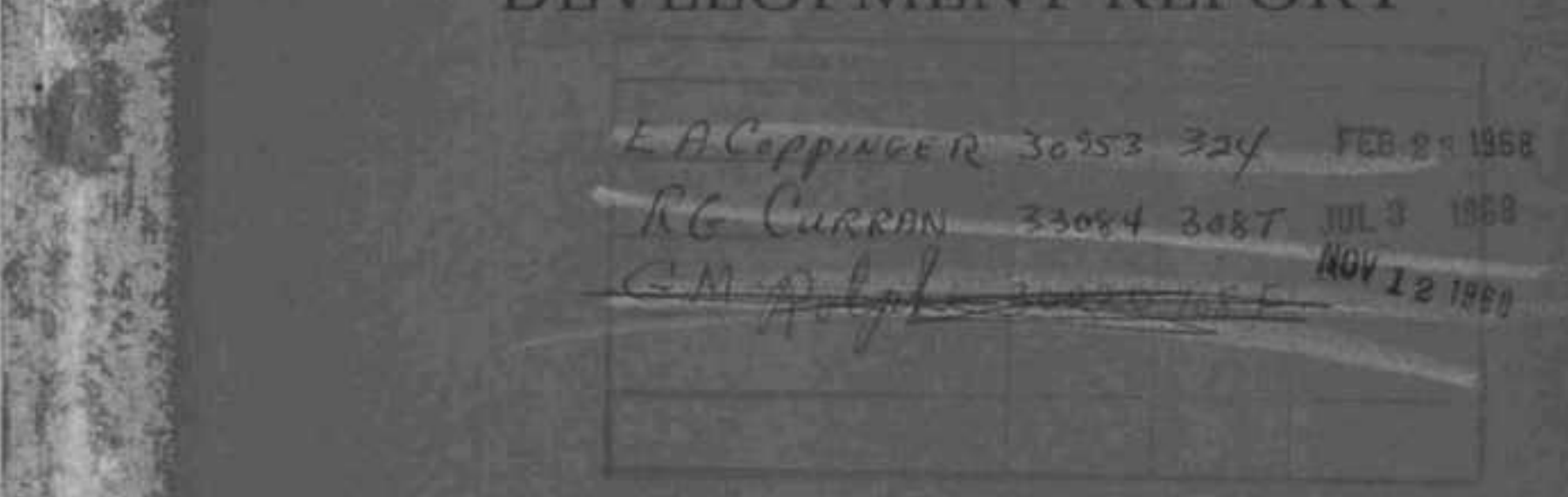




\section{LEGAL NOTICE}

Thin iwport wor preparod an an ucsoury of Government uponsored work. Nelther the Uniled 5totes

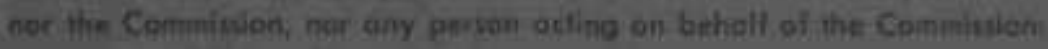

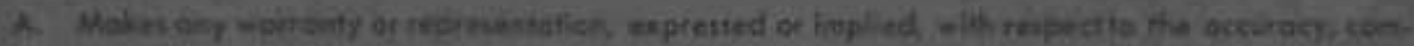

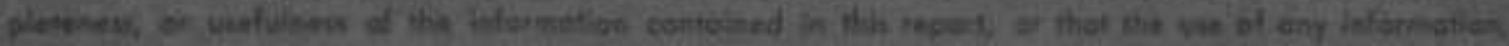

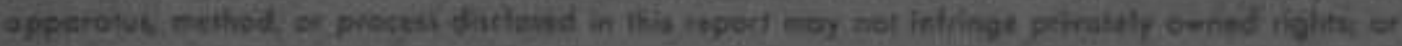

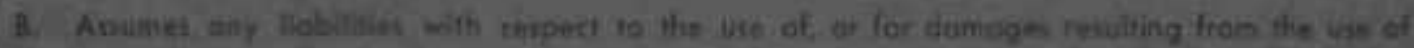

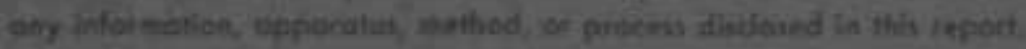

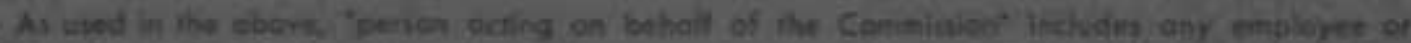

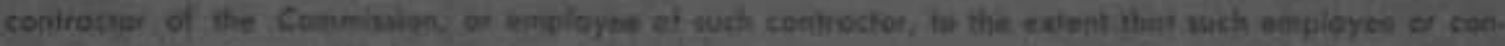

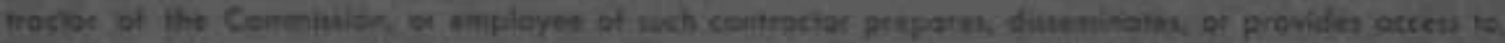

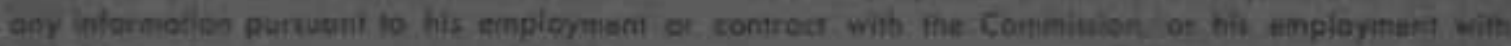
wech cantracion

\section{PACIFIC NORTHWEST LABORATORY}

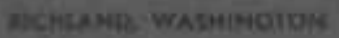

ogeraind by.

BNTTE.IE MEMOHWL INSTIUTE

for the

UNITED STATES ATOMIC ENERGY COMMISSION UNDER CONTRACT ATIS-IH-IBSO 
33679000606634

BiNWL - 519

UC-25, Metals, Ceramies and Materials

NEPTUNIUM TARGET ELEMENT

FABR ICATION

By

C. H. Bloomster

Plutonium Fuels Engineering Section Materials Department

December 1967

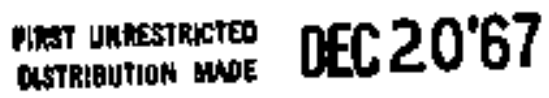

PACIFIC NORTHWEST LABORATORY

RICHLAND, WASHINGTON 
Printed in the United States of America Available from

Clearinghouse for Federal Scientific and Technical Information National Bureau of Standards, U.S. Department of Commerce

Springfield, Virginia 2215 ?

price: Printed Copy $\$ 3.00 ;$ Microfiche $\$ 0.65$ 


\section{NEPTUNIUM TARGET ELEMENT FABRICATION \\ C. H. Bloomster}

\section{ABSTRACT}

A fabrication process was developed for preparing neptunsum-aluminum alloy target elements for irradiation. Some of the target elements included high radiation level, "quick-turn-a round" neptuniun. 


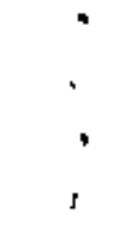




\section{TABLE OF CONTENTS}

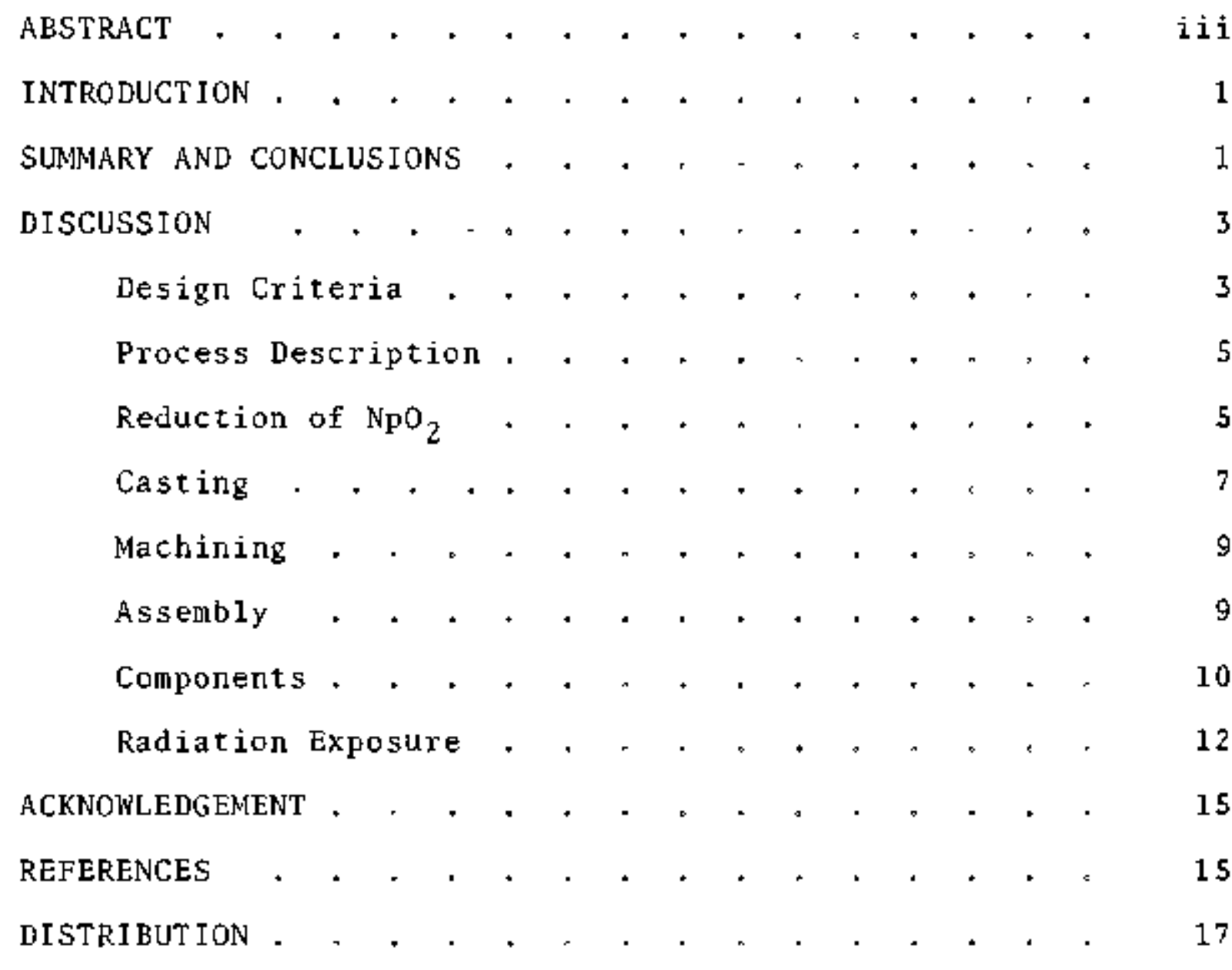


. 


\section{NEPTUNIUM TARGET ELEMENT FABRICATION \\ C. H. B loomster}

\section{INTRODUCTION}

Neptunium target elements were required for irradiation in a K reactor by Douglas United Nurlear (DUN). Battelle-Northwest (BNW) was requested to develop and fabricate the target elements.

DUN was conducting a ${ }^{238} \mathrm{Pu}$ production demonstration program by irradiating neptunium. One of the unique features tas the concept of quick-turn-around in which neptunium from a previous irradiation is recycled back into a reactor in a minmum perlod of time Thls rapld recycle increases ${ }^{238} \mathrm{Pu}$ production and decreases costs. Fifty days, from reactor discharge to recharge, was set as the initial target for the quack-turn-around demonstration The objectives of the target fabrication phase of the program were threefold: 1 development of a fabrication process, 2) demonstration of the fabrication process on quick-turn-around neptunium, and 3) fabrication of all other target elements required for the program.

To meet the quick-turn around objective, a process was required which would have a high yleld and a short, dependable fabrication cycle. In previous work (1) BNW developed an aluminum-neptunium taxget element for arradiation in $N$ reactor. The $K$ reactor target elements, although smaller, were similar in design. Because the fabrication process for the $N$ reactor target elements was highly successful, this process was adapted to the fabrication of the $K$ reactor targets.

\section{SUMMARY AND CONCLUSIONS}

A casting process (Figure l) was developed ro fabricate neptunium target elements for arradiation in $K$ reactor. Process 


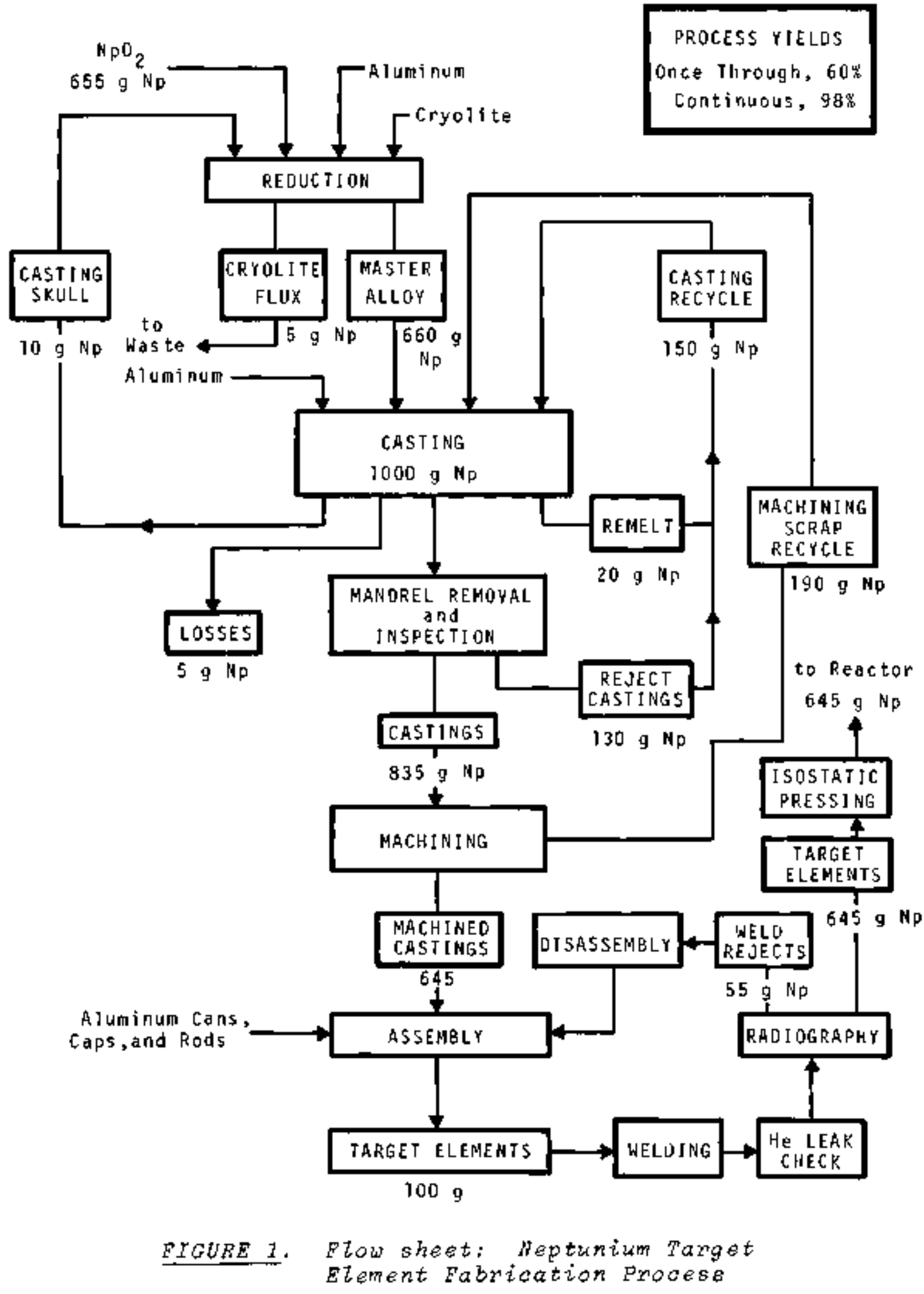


ylelds were good: once-through yields were 60\%, and the con. tinuous process neptunium yield, with recycle, was estimated at $98 \%$.

Fifty targets were fabricated for a ${ }^{238}$ Pu production demonstration program. Five of the targets, which were fabricated in two days, contained quick-turn-around neptunium which was discharged from a reactor only forty days previous. Contact radiation levels from the quick-turn-around neptunlum were high, approximately $20 \mathrm{R}$ bera plus gamma, including $5 \mathrm{R}$ gamma.

Aluminum-neptunium alloys were prepared by reducing neptu. num oxide with aluminum under a cryolite flux. The tubes were machined to specifled lengths and diameters, and inserted into aluminum can assemblies. The complered elements were isostatically pressed to bring the can and core into contact. Scrap was recycled from the casting, machining, and assembly steps by remelting or reassembly overall, $23 \mathrm{Kg}$ of neptunlum entered the process; $20 \mathrm{Kg}$ neptunium went $1 \mathrm{nto}$ the targets, and $0.3 \mathrm{Kg}$ of neptunium scrap remained for recovery at the end of the fabrication

\section{DISCUSSION}

\section{DESIGN CRITERIA}

The following design criteria were established by DUN for the target elements (Figure 2 .

1. For greater neution effociency, the neptunium target materlal will be tubular to concentrate the neptunium atoms on the perlphery of the elements

2. The target material will be an Al-10 wt Np alloy.

3. The center of the tube will contain an aluminum mandrel to add mass to the element to prevent chattering or floating in the process tube.

4 The cladding wild be aluminum.

5 The funshed element will be a solid right cylinder, 1.5 in. diam by 9 in long. 


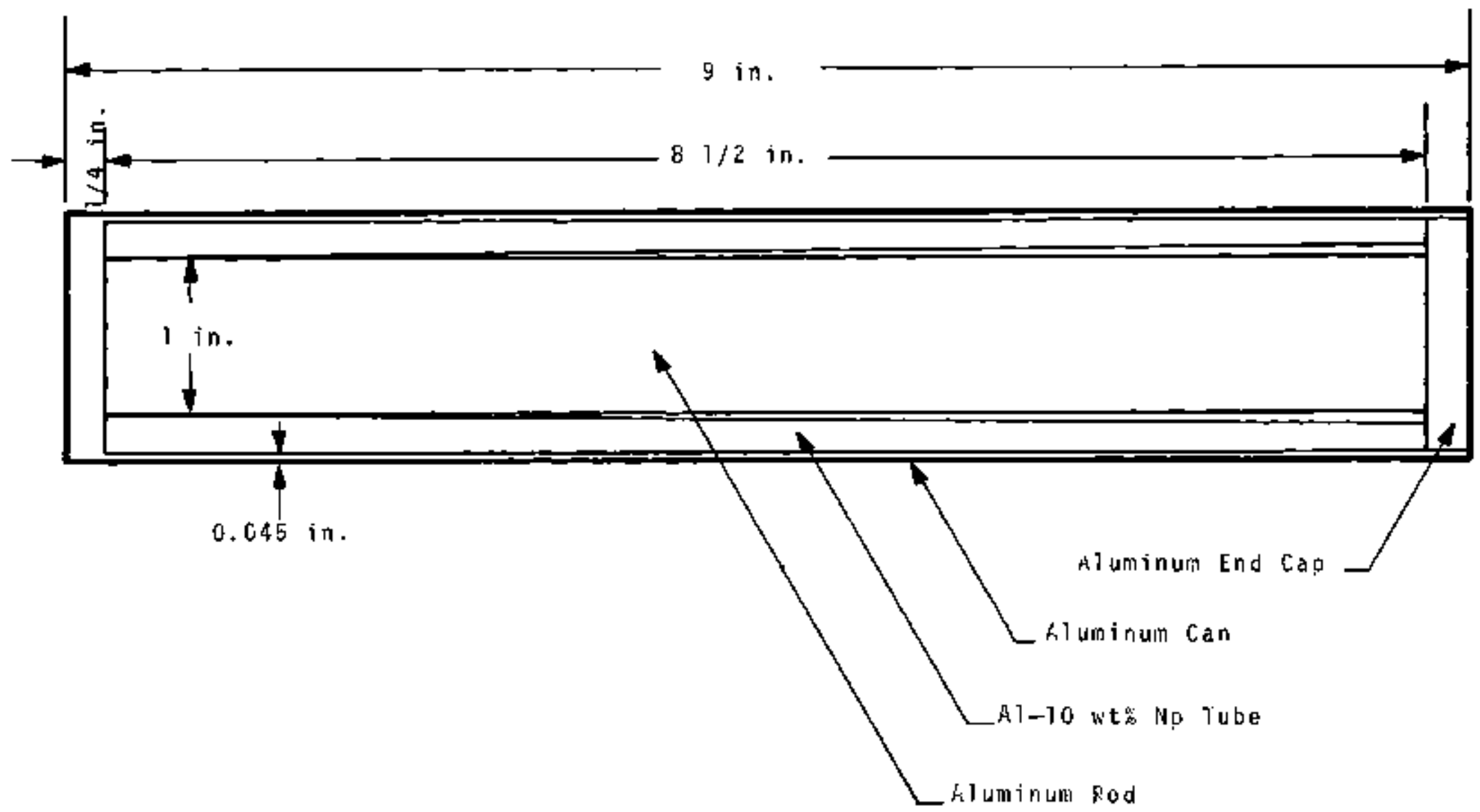

$\leftarrow$

FIGURE 2. Design of Neptunium Target Element 


\section{PROCESS DESCRIPTION}

Neptunium oxide was reduced by aluminum in the presence of cryolite to form an A1-Np master a1loy. The master alloy was diluted with aluminum, if necessary, to 10 wt $\mathrm{Np}$ and cast into thick wall tubes using graphite molds and mandrels. The graphite mandrels were removed from the castings by induction heating. The castings were inspected and machined to specified length and diameter. Each casting and a full-length aluminum rod were inserted into an aluminum can. The weld zone was wiped free of neptunium contamination, and an aluminum end cap was inserted. The elements were welded shut, helium leak-checked, and radiographed. The completely assembled element (Figure 3) was isostatically pressed at 500 psi to eliminate the assembly gaps.

\section{REOUCTION OF $\mathrm{NPO}_{2}$}

Neptunium oxide was reduced by aluminum (in excess) in the presence of cryolite to form an Al-Kp alloy. The reaction is:

$$
3 \mathrm{NpO}_{2}+4 \mathrm{Al}+2 \mathrm{Al}_{2} \mathrm{O}_{3}+3 \mathrm{~Np} \text {. }
$$

The neptunium alloys with the excess aluminum, and the $\mathrm{Al}_{2} \mathrm{O}_{3}$ product was dissolved by the cryolite flux. The reductions were made at $1200^{\circ} \mathrm{C}$. The reaction was judged complete $30 \mathrm{~min}$ after is appearance of the green neptunium oxide color from the white cryolite. Reaction times usually ranged between 60 and 90 minutes. After the reduction was complete, the cryolite was skimmed from the melt, and the melt was cast into billets.

Three separate reductions of $\mathrm{NPO}_{2}$ were made (Table I). High purity aluminum, 99.998 , was used for alloying. The reductions were made in induction melting furnaces housed in an air-atmosphere glove box. The melt charges were calculated to obtain a master alloy of $13 \mathrm{wt} N \mathrm{~N}$ in the first reduction, and $10 \mathrm{wt} \mathrm{Np}$ in the last two reductions. 


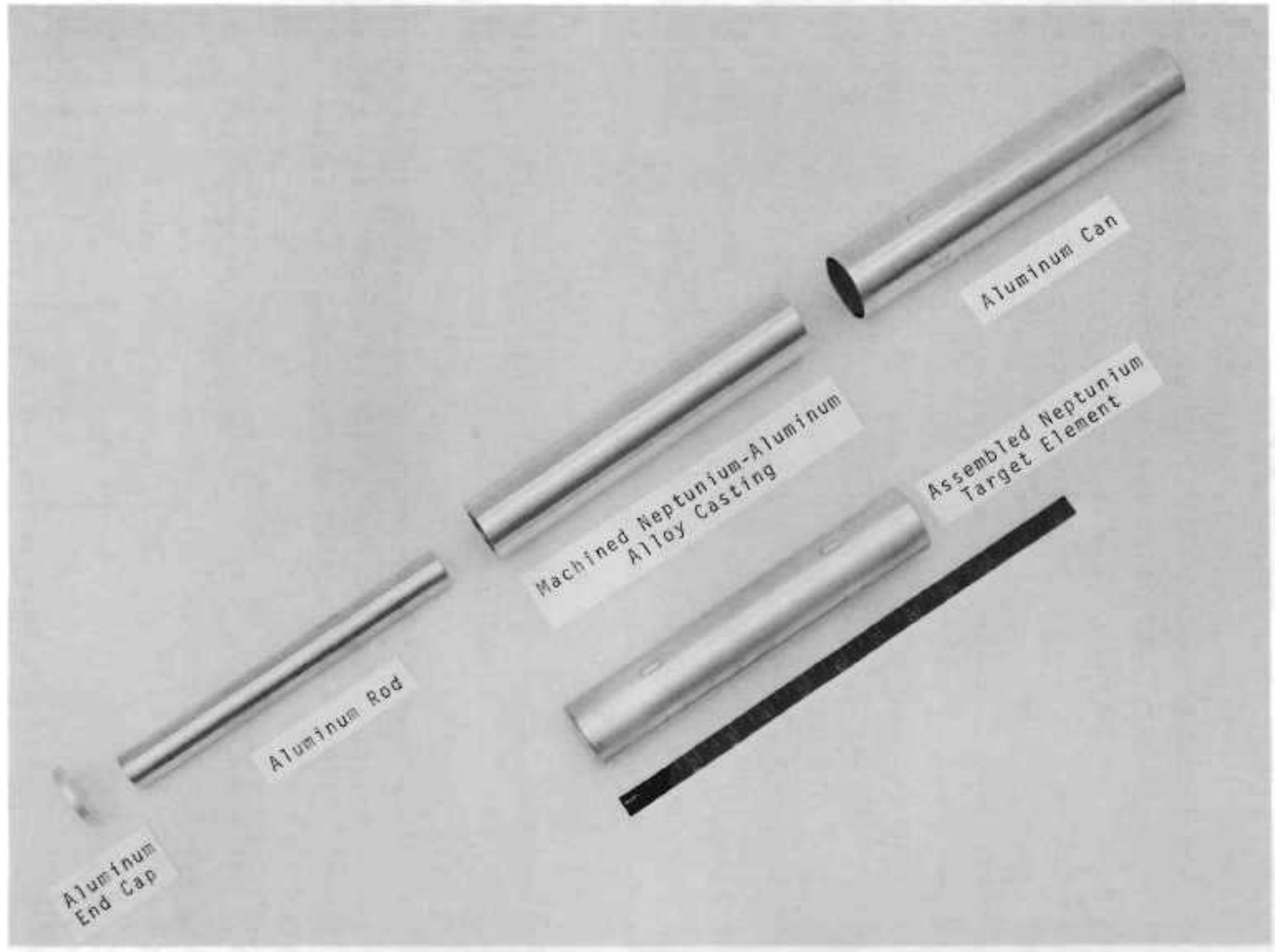

a

范

EIGURE 3. Neptunium Target Etement and Component Parts 
TABLEI. Reduction of ipo, with A tuminum

\begin{tabular}{|c|c|c|c|c|c|}
\hline \multirow[b]{2}{*}{$\begin{array}{c}\text { Melt } \\
\text { Number }\end{array}$} & \multicolumn{4}{|c|}{ charge, g } & \multirow{2}{*}{$\begin{array}{l}\text { Yield, g } \\
\begin{array}{c}\text { Np-A1 } \\
\text { Alloy }\end{array} \\
\end{array}$} \\
\hline & $\mathrm{Np}_{2}{ }_{2}$ & $\begin{array}{c}\text { Np-Al } \\
\text { Recycle }\end{array}$ & Aluminum & Cryolite & \\
\hline 1 & 554 & & 3,342 & 1400 & 3,660 \\
\hline 2 & 278 & & 2,242 & 800 & 2,386 \\
\hline 3 & 1784 & 1046 & 13,912 & 3500 & 16,004 \\
\hline
\end{tabular}

Material balances were calculated for the last five $\mathrm{NpO}_{2}$ reductions, including the last two reductions from the fabrication of the $\mathrm{N}$ reactor targets; (1) $\mathrm{Np}$ recovery was $98.8 \%$ in alloy form, with 0.7 into the waste cryolite flux, and $0.5 \%$ in losses. The last five reductions contained $5.26 \mathrm{Kg}$ Neptunium. The sampling of the waste cryolite was not extensive; further work is required to verify the distribution of neptunium between the cryolite waste and the process losses.

\section{CASTING}

The master alloy was remelted and diluted, as necessary, to an A1-10 wt Kp a1loy. The A1-Np alloy was cast into $1 / 4$ in. thick wall tubes in a graphite mold around graphite mandrels (Figure 4). The graphite mandrels were tapered to facilitate later removal. To reduce scrap generation in the machining operation the casting was made 0.05 in. oversize on the $O D$, and the ID was cast to the desired size. The melt was made in an induction melting crucible and poured into a casting ladle, a No. 5 clay-graphite crucible preheated in a resistance furnace. The casting temperature was $735^{\circ} \mathrm{C}$ to $740^{\circ} \mathrm{C}$; the mold and mandrels were preheated to $300^{\circ} \mathrm{C}$. A hand-ladling technique was used to produce castings having low porosity, good surfaces, uniform neptunium concentrations, and high yields. Proper casting technique was important. The metal was initially poured rapidly, slowing to a trickle near the end of the pour. 


$$
\text { III }
$$


The mold was supported on a copper block to promote directional solidification. The mold was rotated slowly by hand to prevent local overheating of the graphite mandrel. After casting, the mandrel was removed by induction reheating of the casting. The castings were inspected and radiographed to detect unsoundness and segregation.

The only casting defect encountered during fabrication was excessive solidification shrinkage near the inner top of the casting. This was caused by localized overheating at the point where the molten stream impinged on the mandrel. The defect was not serious, for the structural strength requirement of the castings was very low ( $4500 \mathrm{psi})$. The casting defect was eliminated by a combination of the proper pouring rate and mold rotation, The casting yield was $84 \%$; the casting rejects were entirely recycled. With further experience, the casting yield should exceed $90 \%$.

MACHINING

The cast tubes were cut to length. Turnings for chemical analysis were taken from each end. The outside diameter was machined to size in one pass by using live centers. No lubricants or cutting fluids were used in machining. The machined pieces were handled carefully with tongs to prevent surface contamination, inserted in plastic bags, and weighed before transfer to the assembly area. The yield from the machining operation was $77 \%$ of the cast alloy weight. Machining scrap [chips (19\%) and rejects (4) of the cast alloy weight] was recycled through the casting operation.

\section{ASSEMBLY}

Assembly was performed in a fume hood. Each casting and the aluminum rod were carefully inserted into an aluminum can. 
F1ux detectors, full-length Al-Co wires (bare and Cd clad), were assembled into four elements. Grooves were filed on the outside of two castings for the wires, and the other two wires were located inside the castings by a peening at tachment to the aluminum rods. The weld zone was wiped free of contamination, and the end cap was inserted. During the assembly of the first fifteen target elements, considerable tıme was spent cleaning the weld zone. Small chips were detected clinging to the surface of the machined castings. Thereafter, before assembly, the machined castings were cleaned by soaking in perchlorethylene and dried by the natural air flow through the fume hood. Decontamination of the weld zone seemed easier after the solvent cleaning. Welding (TIG) was performed in a welding box by using direct current, a tungsten electrode, and a helium atmosphere.

The welded assemblies were free from contamination and were handled in the open laboratory. The elements were inspected for marred surfaces, helıum leak-checked, and radiographed.

The assembly $y$ ield was $92 \%$, The assembly rejects resulted entirely from incomplete weld penetration. The assembly rejects were simply recanned.

The target elements were finished by cold isostatic pressing in water at $500 \mathrm{psi}$ to eluminate assembly gaps. Target element ldentification, weight, and analytical data are summarized in Table II.

COMPONENTS

Standard aluminum cladding components $(99+\%$ A1) were supplied by DUN. The components were cleaned and etched using conventional techniques. The aluminum can was fully annealed to facilitate the isostatic pressing operation. A plug gage was used to test all aluminum cans prior to assembly. 
PABLE II. Parget Element Data

\begin{tabular}{|c|c|c|c|c|c|c|}
\hline \multicolumn{2}{|c|}{$\begin{array}{c}\text { Element } \\
\text { No. }\end{array}$} & \multicolumn{2}{|c|}{$\begin{array}{c}\text { Casting } \\
\text { No. }\end{array}$} & \multirow{2}{*}{$\begin{array}{c}\text { Weight } \\
\text { of Machined } \\
\text { Casting, g } \\
386.5\end{array}$} & \multirow{2}{*}{$\frac{\frac{N p}{A n a l y s i s,}}{10.6}$} & \multirow{2}{*}{$\frac{\begin{array}{c}\text { Np } \\
\text { Content }\end{array}}{41.0}$} \\
\hline NEP & $1-1$ & $N P C 1$ & - $\mathrm{B}$ & & & \\
\hline & 2 & 2 & $-\mathrm{C}$ & 383.9 & 10.6 & 40.7 \\
\hline & 3 & 2 & $-D$ & 386.3 & 10.6 & 40.9 \\
\hline & 4 & 1 & $-\mathrm{D}$ & 386.3 & 10.6 & 40.9 \\
\hline & 5 & 2 & $-B$ & 388.5 & 10.6 & 41.2 \\
\hline & 6 & 3 & $-B$ & 388.9 & 10.6 & 41.2 \\
\hline & 7 & 3 & $-\mathrm{A}$ & 387.3 & 10.6 & 41.1 \\
\hline & 8 & 1 & $-F$ & 389.9 & 10.6 & 41.3 \\
\hline & 9 & 1 & $-E$ & 382.1 & 10.6 & 40.5 \\
\hline & 10 & 2 & $-E$ & 390.3 & 10.6 & 41.4 \\
\hline & $2-1$ & 4 & $-A$ & 384.1 & 10.0 & 38.4 \\
\hline & 2 & & B & 385.7 & 10.0 & 38.6 \\
\hline & 3 & & C & 384.0 & 10.0 & 38.4 \\
\hline & 4 & & D & 382.8 & 10.0 & 38.3 \\
\hline & 5 & & E & 384.0 & 10.0 & 38.4 \\
\hline & $3-1$ & 5 & $-U$ & 388.2 & 9.8 & 38.0 \\
\hline & 2 & & S & 384.8 & 9.8 & 37.7 \\
\hline & 3 & & $\mathrm{D}$ & 389.9 & 9.8 & 38.2 \\
\hline & 4 & & W & 387.4 & 9.8 & 38.0 \\
\hline & 5 & & $\mathrm{U}$ & 386.8 & 9.8 & 37.9 \\
\hline & 6 & & K & 383.2 & 9.8 & 37.6 \\
\hline & 7 & & 0 & 387.3 & 9.8 & 38.0 \\
\hline & 8 & & B & 386.6 & 9.8 & 37.9 \\
\hline & 9 & & L & 383.7 & 9.8 & 37.6 \\
\hline & 10 & & $B$ & 383.9 & 9.8 & 37.6 \\
\hline & 11 & & I & 387.5 & 9.8 & 38.0 \\
\hline & 12 & & $\mathrm{~J}$ & 386.8 & 9.8 & 37.9 \\
\hline & 13 & & $A A$ & 388.0 & 9.8 & 38.0 \\
\hline
\end{tabular}




\section{TABLE II, (Contd)}

\begin{tabular}{|c|c|c|c|c|c|c|}
\hline \multicolumn{3}{|c|}{$\begin{array}{c}\begin{array}{c}\text { Element } \\
\text { No. }\end{array} \\
\end{array}$} & $\begin{array}{c}\text { Casting } \\
\text { No. }\end{array}$ & $\begin{array}{c}\text { Weight } \\
\text { of Machined } \\
\text { Casting, } 8 \\
\end{array}$ & \begin{tabular}{c}
$\mathrm{Np}$ \\
Analysis, \\
\hdashline \\
\end{tabular} & $\begin{array}{c}N p \\
\text { Content } \\
\end{array}$ \\
\hline \multirow[t]{23}{*}{ NEP 3} & $3-$ & 14 & R & 382.2 & 9.8 & 37.5 \\
\hline & & 15 & C & 383.8 & 9.8 & 37.6 \\
\hline & & 16 & $\mathrm{DD}$ & 385.2 & 9.8 & 37.7 \\
\hline & & 17 & $\mathrm{H}$ & 385.9 & 9.8 & 37.7 \\
\hline & & 18 & $\mathrm{~N}$ & 389.7 & 9.8 & 38.2 \\
\hline & & 19 & $E$ & 382.7 & 9.8 & 37.5 \\
\hline & & 20 & $Q$ & 385.2 & 9.8 & 37.7 \\
\hline & & 21 & $Y$ & 388.2 & 9.8 & 38.0 \\
\hline & & 22 & $x$ & 385.9 & 9.8 & 37.7 \\
\hline & & 23 & $\mathrm{M}$ & 386.2 & 9.8 & 37.8 \\
\hline & & 24 & $c c$ & 386.9 & 9.8 & 37.9 \\
\hline & & 25 & 2 & 387.6 & 9.8 & 38.0 \\
\hline & & 26 & $\mathrm{~F}$ & 385.7 & 9.8 & 37.7 \\
\hline & & 28 & A & 387.5 & 9.8 & 38.0 \\
\hline & $4-$ & 1 & $6-H$ & 388.4 & 9.9 & 38.5 \\
\hline & & 2 & C & 386.3 & 9.9 & 38.2 \\
\hline & & 3 & I & 389.8 & 9.9 & 38.6 \\
\hline & & 4 & G & 389.2 & 9.9 & 38.5 \\
\hline & & 5 & A & 389.2 & 9.9 & 38.5 \\
\hline & & G & $\mathrm{D}$ & 389.2 & 9.9 & 38.5 \\
\hline & & 7 & B & 387.4 & 9.9 & 38.4 \\
\hline & & 8 & E & 388.2 & 9.9 & 38.4 \\
\hline & & 9 & F & 390.8 & 9.9 & 38.7 \\
\hline
\end{tabular}

\section{RADIATION EXPOSURE}

One of the problems associated with quick-turn-around neptunium is the high radiation levels associated with the decay of 
$238 \mathrm{~Np}$, the interim product of $237 \mathrm{~Np}$ irradiation. Neptunium-238 has a 2.1 day half-1ife, and beta decays to ${ }^{238}$ Pu. Neptunium-237, itself, decays by alpha emission to ${ }^{233} \mathrm{~Pa}$. Protactinium-233 emits a 0.31 MeV photon which also produces an appreciable radiation field. Radiation levels from newly separated irradiated neptunium decrease rapidly as the $238 \mathrm{~Np}$ decays and then increases with the ${ }^{233} \mathrm{~Pa}$ buildup. Equilibrium ${ }^{233} \mathrm{~Pa}$ concentration is reached in approximately 160 days. Minimum radiation levels occur in approximately 50 days from reactor discharge.

Contact radiation levels from the $300 \mathrm{~g}$ batch of quick-turnaround $\mathrm{NpO}_{2}$ available for target fabrication were $220 \mathrm{R}$ beta plus gamma and $5 \mathrm{R}$ gamma. (2) Radiation measurements of the finished target elements are shown in Table III. (3)

Personnel exposures during the target fabrication were quite high, considering the small quantities of neptunium involved, but only minor amounts of shielding were used. Insofar as practical, the work piece was separated from the warking stock and unnecessary contact was avoided. Selfreading dosimeters were used to control personnel exposure. larger scale fabrication may require instaliation of heavler shrelding (particularly in the machining and assembly operations) and modification of some handling techniques to reduce personnel exposure. Adoption of remote handing techniques, however, should not become necessary. 
TABLE III. Corrected Dose Rates from ${ }^{237} \mathrm{~Np}$ Target Elements

Units of mrad/hr

Elements contain $40 \mathrm{~g} 237 \mathrm{~Np}$ each

\begin{tabular}{|c|c|c|c|c|c|c|}
\hline \multirow[b]{2}{*}{ Distance* } & \multicolumn{2}{|c|}{ Measured on $4 / 14 / 67$} & Measured & \multirow{2}{*}{$\begin{array}{l}\text { on } 4 / 26 / 67 \\
\text { Array } \\
5 \text { elements }\end{array}$} & \multicolumn{2}{|c|}{ Measured on $5 / 15 / 67^{\dagger}$} \\
\hline & $\begin{array}{c}\text { Element No. } \\
1-8\end{array}$ & $\begin{array}{l}\text { Array } \\
10 \text { elements } \\
\text { el }\end{array}$ & $\begin{array}{c}\text { Element No. } \\
4-\mathrm{A} .\end{array}$ & & $\begin{array}{c}\text { Element No. } \\
3-2\end{array}$ & $\begin{array}{l}\text { Array }{ }^{\star *} \text { of } \\
10 \text { elements }\end{array}$ \\
\hline Contact & 1635 & 2700 & 3350 & 5200 & 1970 & 4100 \\
\hline 2 in. & -- & $\ldots$ & 310 & 2090 & $\ldots$ & \\
\hline 3 in. & 100 & $B 15$ & -- & & 135 & 1250 \\
\hline 4 in. & -- & -- & 210 & 1075 & $\cdots$ & \\
\hline 6 in. & 50 & 560 & 130 & 680 & 70 & 640 \\
\hline 9 in. & --- & --- & -- & & 38 & 295 \\
\hline 12 in. & 20 & 200 & 50 & 250 & 27 & 215 \\
\hline $15 \mathrm{in}$. & $=-$ & $=$ & $\cdots$ & & 21 & 165 \\
\hline 18 in. & 10 & 100 & 22 & 140 & 17 & 120 \\
\hline $24 \mathrm{in}$. & 6 & 65 & 14 & 80 & 12 & 80 \\
\hline 36 in. & 3 & 31 & 8 & 40 & 7 & 36 \\
\hline $48 \mathrm{in}$. & 2 & 20 & 5 & 18 & 5 & 23 \\
\hline
\end{tabular}

* Wistance was measured from the screen of the CP instrument to the surface of the elements(s).

** In the "array" geometry, the elements were placed side by side at approximately equal distances from the CP screen.

+ The readings made on 5/15/67 may be slightly high because of background radiation in the area. 


\section{ACKNOWLEDGEMENT}

The author gratefully acknowledges the cooperation and assistance of Joe Jensen, Clarence Munson, and Ray Reid (BNW), and Fred Lewis, Jim Michaelson, and Ed Epperson (DUN) in the preparation of the elements. Radiation Monitoring information was provided by Dan McConnon and Analytical Services by hayne Delvin and Clyde Leaf,

\section{$\underline{\text { REFERENCES }}$}

1. C. H. Bloomater. Preparation of Neptunium-tiuminum Alloy Target Elements, BNWL-311. Pacific Northwest Laboratory, Richland, Washington, october, I966. (officiat Use only)

2. R. S. Kingsiey. Unpublished Data, Isochem, Incorporated, Richland, Washington, Aprit, 1267. (Personat Communication)

3. D. MoConnon. Np-237 Taraet Element Dose Rates, Unpublished Data. Paetfic Northwest Laboratory, Richtand, Washington, May 23, I367. (Personal Commurication) 
r 


\section{DISTRIBUTION}

No. of

Copies

AEC Chicago Patent Group

R. K. Sharp

AEC Division of Technical Information Extension

AEC RDT Site Representative - PNL

P. G. Holsted

7

AEC Richland Operations Office

M. H. Arndt (3)

o. W. Rathbun

C. L, Robinson

Technical Information Library

4

Atlantic Richfield Hanford Company

L. E. Bruns

O. F. Hill

R, S. Kingsley

M. Szulinski

19

Douglas United Nuclear

T. W. Ambrose

F. Bouse (3)

P. A. Carlson

D. W. Constable

$R$, Cooperstein

D. H. Curtiss

E. M. Epperson

L. E. Kusler

G. A. Huff

$M$. Lewis

J. W. Nickolaus

J. L. Nosler

F. E. Owen

G. F. Ows Iey

J. W. Riches

J. T. Stringer

H, F, Tew

Battelle-Northwest

F. W. Albaugh

H. J. Anderson 
Batte11e-Northwest (contd)

R, J. Anicetti

D. E. Blahnik

C. H. Bloomster (15)

S. H. Bush

J. J. Cadwe11

R. G. Curran

G. M. Dalen

D. R. deHalas

D. E. Deonigi

R. F. Dickerson

K. Drumbe11er (2)

E. A. Eschbach

E. A. Evans

T. W. Evans

S. L. Fawcett

S. Goldsmith (2)

3i. L. Hampson (2)

J. J. Hauth

D. McConnon

L. G. Merker

R. S. Paul

H. M. Parker

R. W. Stewart

H. A. Taylor (2)

H. H, Van Tuy 1

E. E. Voil and

O. J. Wick

N. R. Wisely

Technical Information Files (5)

Technical Publications ( 2 ) 